\title{
Antihyperglycemic, Antihyperlipidemic and Antiapoptotic Activities of Micromelum minutum Seeds in Diabetic Rats
}

\author{
Khaled MM Koriem ${ }^{1,2 *}$, Muhammad E Aminuddin ${ }^{3}$, Azham S Kader ${ }^{3}$ and Noruddin R Sheikh \\ ${ }^{1}$ Advanced Medical and Dental Institute (AMDI), Universiti Sains Malaysia (USM), Malaysia \\ ${ }^{2}$ Medical Physiology Department, National Research Centre, Dokki, Giza, Egypt \\ ${ }^{3}$ Faculty of Medicine and Health Sciences, Universiti Putra Malaysia, Malaysia \\ ${ }^{4}$ Department of Biochemistry, Faculty of Biotechnology and Biomolecular Sciences, Universiti Putra Malaysia, Malaysia
}

\begin{abstract}
Diabetes mellitus is one of the most common chronic diseases in the whole world. It is a complex, multi-factorial disease which affects the quality, quantity, and style of an individual's life. The Micromelum minutum (Family Rutaceae) is a small shrub growing widely in Southeast Asia and the Pacific Islands. In the present study the evaluation of the anti-hyperglycemic, anti-hyperlipidemic and anti-apoptotic activities of Micromelum minutum seeds ethanolic extract in diabetic rats was done. After 30 days of administration the dose $(100 \mathrm{mg} / \mathrm{kg}$ body weight (bwt) of ethanolic extract of the Micromelum minutum seeds and $25 \mathrm{mg} / \mathrm{kg}$ bwt Microminutinin coumarin there was a significant decrease in serum glucose levels; while following two months of administration of the same doses of the seeds extract and coumarin induced a significant decrease in the cholesterol, triglycerides and low density lipoprotein (LDL) levels and increase in the high density lipoprotein (HDL) level. The treatment with Micromelum minutum seeds extract and its coumarin ingredient to diabetic rats increased $p 53$ expression while decreased bcl- 2 expression. Histopathological investigation revealed that Micromelum minutum seeds ethanolic extract $(100 \mathrm{mg} / \mathrm{kg}$ ) and Microminutinin coumarin $(25 \mathrm{mg} / \mathrm{kg}$ bwt) treatment also increased the number of pancreas $\beta$-cells as compared to that of diabetic animals. In conclusion, Micromelum minutum seeds ethanolic extract had anti-hyperglycemic, anti-hyperlipidemic and anti-apoptotic activities and all these activities are related to Microminutinin coumarin ingredient of the plant seeds.
\end{abstract}

Keywords: Hyperglycemia; Hyperlipidemia; Apoptosis; Micromelum minutum; Microminutinin; Rats

\section{Introduction}

Diabetes mellitus is one of the most common chronic diseases in the whole world. It is a complex, multi-factorial disease which affects the quality, quantity, and style of an individual's life [1]. Diabetes mellitus is a chronic metabolic disorder, mainly characterized by disruption in carbohydrates, protein, and fat metabolism caused by the complete or relative insufficiency of insulin action [2]. When the amount of blood glucose in the blood increases, for example, after a meal, it triggers the release of the hormone insulin from the pancreas. Insulin stimulates muscle and fat cells to remove glucose from the blood and stimulates the liver to convert glucose to glycogen, causing the blood sugar level to decrease to the normal level and consequently stimulate pancreas to secret glucagon hormone to increase blood glucose level where glucagon causes the liver to convert stored glycogen into glucose and high amount of glucose is circulating in the blood (hyperglycemia). To keep the normal level of glucose in blood, the kidney removes the extra sugar from the blood and excretes it in the urine. Hyperglycemia can be handed initially with oral synthetic agent and insulin therapy. But these synthetic agents produce some serious side effects and are relatively expensive for developing countries $[3,4]$.

The research for a new and natural source to be used in the treatment of diabetes was increased in the last decade. The medicinal plants provide a new, avaliable and cheap source for developing new drugs nowadays. Natural products account for more than $40 \%$ of all pharmaceuticals on the market today, where from 1941 to 2002, over $50 \%$ of all the drugs, or new drug entities, available for cancer treatment were derived from natural resources [5]. The dependence of large rural population on medicinal plants for treatment of diabetes is because of its availability and affordability [6]. Additionally, after the approbation made by WHO on diabetes mellitus, exploration on hyperglycemic agents from medicinal plants has become more significant [7].

The Micromelum minutum (Family Rutaceae) is a shrub that reaches up to $3 \mathrm{~m}$ in height, growing widely in Southeast Asia and the Pacific Islands. Its synonym is Micromelum pubescens Blume [8] and is known in Malaysia as chemomar, cherek or kematu. The leaves are used traditionally as a febrifuge, the stems as a carminative, and the flowers and fruits as an expectorant and a purgative, respectively [9]. The genus Micromelum species are known to contain 6- and 8-prenylated coumarins [10-12]. Micromelum minutum seeds was chosen for current study because the seeds are rich source of coumarins. Previous investigation of the leaves of the plant led to the isolation of bioactive coumarin derivatives such as microminutin [13], flindersine, 7,8-dioxygenated coumarins, and triterpenes [13-15], as well as a pyranoquinoline alkaloid [13]. Lekphrom et al. [16] isolated a new 7-oxygenated coumarin, 7-demethylmurralonginol isovalerate, and murralonginol, together with seven known coumarins (7-oxygenated coumarins, murralonginol isovalerate, murralongin, micromelin, scopoletin, microminutin, murrangatin, and minumicrolin, from the fruits of Micromelum minutum. The methanolic extract of Micromelum

*Corresponding author: Khaled MM Koriem, Integrative Medicine Cluster Advanced Medical and Dental Institute (AMDI), Universiti Sains Malaysia (USM) Malaysia, Tel: 604-5622413; Fax: 604-5622349; E-mail: kkoriem@yahoo.com

Received October 0267, 2013; Accepted December 10, 2013; Published December 16, 2013

Citation: Koriem KMM, Aminuddin ME, Kader AS, Sheikh NR (2013) Antihyperglycemic, Antihyperlipidemic and Antiapoptotic Activities of Micromelum minutum Seeds in Diabetic Rats. J Mol Genet Med S1: 004. doi: 10.4172/1747-0862. S1-004

Copyright: @ 2013 Koriem KMM, et al. This is an open-access article distributed under the terms of the Creative Commons Attribution License, which permits unrestricted use, distribution, and reproduction in any medium, provided the original author and source are credited 
minutum exhibit the highest antimutagenic activity in Mutagens, Trp-P-1 among 118 samples (108 species) of edible thailand plants was examined by the Ames Test [17]. Micromelum minutum leaves showed cytotoxic activity against leishmania major and cancer cells (lung adenocarcinoma and leukaemia) [18].

This study was conducted to investigate the anti-hyperglycemic, anti-hyperlipidemic and anti-apoptotic activities of Micromelum minutum seeds ethanolic extract in diabetic rats.

\section{Materials and Methods}

\section{Materials}

Plant material: Micromelum minutum seeds were provided from Horticulture Department, Ministry of Agriculture, Kuala Lumpur in May 2011. The plant was botanically identified authenticated by Prof. Zhari at the School of Pharmacy, Universiti Sains Malaysia, Malaysia. Voucher specimen of each plant was deposited at the herbarium of the School of Pharmacy. The seeds were crushed, pulverized and then weighed and prepared for extraction.

Preparation of the ethanolic extract: Micromelum minutum seeds $(1.5 \mathrm{~kg})$ were air-dried in an oven at $40^{\circ} \mathrm{C}$ for 4 days and then the dry plant was cut and pulverized. Dried Micromelum minutum seeds (500 g) were placed in $1000 \mathrm{ml}$ of distilled boiling water and kept at room temperature for $15 \mathrm{~min}$. The dried powdered plant material was macerated for 7 days using $70 \%$ ethanol as a solvent. The solvent was then eliminated by a rotary vacuum evaporator under reduced pressure and the subsequent extract lyophilized, representing a yield of $15 \%$ of the dry material extracted. The extract was evaporated to dryness to give dried ethanolic extract ( $150 \mathrm{~g}$ ) according to the method of Chopra et al. [19]. The extraction process was taken one month from collection of the plant seeds until final ethanolic extract was obtained.

Ethanolic extract purity, quality and stability methods: Purity tests (Microbiological, Pesticide residues, Heavy metals, Radioactive residues, Chemical, Foreign organic matter and Sulfated ash) were performed in accordance with Malaysian accepted protocol requirements and accredited to ISO/IEC 17025 consult the WHO guidelines on stability and quality controls methods for medicinal plants $[20,21]$. The plant extract was stored in a tightly cooling $\left(-4^{\circ} \mathrm{C}\right)$ sealed container away from heat and light that prevent any loss of extract solvent and entry of water; where plant extract dissolved in $1 \mathrm{ml}$ distilled water and given orally to individual rat.

Determination of lethal dose fifty $\left(\mathrm{LD}_{50}\right)$ of Micromelum minutum extract: Forty adult albino rats were used in this study and divided into 5 equal groups each of 8 rats. The $\mathrm{LD}_{50}$ of the extract was determined in $\mathrm{mg} / \mathrm{kg}$ body weight [22], where $\mathrm{LD}_{50}=\mathrm{DM}-\Sigma \mathrm{Z} . \mathrm{d} / \mathrm{m}, \mathrm{DM}=$ the highest dose used, $Z=$ the number of dead rats of two successive doses divided by two, $\mathrm{d}=$ difference between two successive doses, $\mathrm{m}=$ the number of rats in each group. Administrations with oral $10 \%$ of the $\mathrm{LD}_{50}$ of the extract were found to be safe [23].

Thin layer chromatography (TLC) for coumarins isolation: TLC was used to resolve and isolate the coumarins constituents from the plant extract. Dried seeds of the plant were extracted with acetone at room temperature. The ethanol extract $(2.36 \mathrm{~g})$ was subjected to silicagel column chromatography eluting with hexane and hexane-acetone $(7: 3,3: 2,1: 1,1: 4)$, successively, to give 6 fractions. Each fraction was further subjected to silica-gel column chromatography and preparative TLC with appropriate combinations of hexane, $\mathrm{CH}_{2} \mathrm{Cl}_{2}$, iso- $\mathrm{Pr}_{2} \mathrm{O}$, benzene, $\mathrm{CHCl}_{3}, \mathrm{EtOAc}$, acetone, and $\mathrm{MeOH}$ as developing solvents to give another six coumarins as described in the results below.

Animals: Adult male diabetic albino rats of Sprague Dawley strain weighing 200-220 g were obtained from animal house colony of Universiti Sains Malaysia hospital (HUSM), Kelantan, Malaysia. They were kept under the hygienic conditions and well balanced diet and water. The experiments were carried out according to the National regulations on animal welfare and Institutional Animal Ethical Committee (IAEC).

Drugs: a) Glibenclamide(Glibamide ${ }^{\circledR}$ ) was purchased from pfizer Pharmaceutical Company, Malaysia; as a standard hypoglycemic drug.

b) Atorvastatin (Atortatin ${ }^{\circ}$ ) was obtained from Penang Pharmaceutical Company, Malaysia; as a standard hypolipidemic drug.

c) Kits reagents obtained from Biomerieux Company through local supplier for measuring serum glucose, triglycerides and total cholesterol fractions. Doses of drugs used were calculated according to Paget and Barnes [24] administered orally by gastric tube. The extract is also administered orally by a gastric tube.

\section{Methods}

Induction of diabetes: Hyperglycemia was induced by injecting streptozotocin (STZ) at a dose of $150 \mathrm{mg} / \mathrm{kg}$ intraperitoneall (ip) and the animals were kept under observation. After $48 \mathrm{hrs}$, the animals were tested for blood glucose using enzymatic colorimetrical method [25]. Twelve days after the STZ injection, rats with fasting blood glucose levels greater than $200 \mathrm{mg} / \mathrm{dl}$ were considered diabetic.

Determination of anti-hyperglycemic and anti-hyperlipidemic activities: Five groups each of 8 diabetic rats were used for both anti-hyperglycemic and anti-hyperlipidemic activities. In antihyperglycemic group, the first group was kept as negative control administered saline orally. The second group is diabetic rats. The $3^{\text {rd }}$ group; diabetic rats treated orally with Glibenclamide $(2.5 \mathrm{mg} / \mathrm{kg})$ was used as reference positive control drug suspended in saline [26]. The $4^{\text {th }}$ group; diabetic rats treated daily with oral dose of $100 \mathrm{mg} / \mathrm{kg}$ bwt of the ethanolic extract of Micromelum minutum seeds; while the $5^{\text {th }}$ group; diabetic rats received daily an oral dose of $25 \mathrm{mg} / \mathrm{kg}$ bwt of Microminutinin coumarin for 15 days and 30 days, respectively. At zero time, 15 \& 30 days after administration of negative and positive controls as well the extract and coumarin, blood samples were collected from the retro-orbital plexus through the canthus of the anesthetized rats after an overnight fasting and serum was isolated by centrifugation and total blood glucose was determined.

In anti-hyperlipidemic group the animals were divided also into 5 groups; first group was kept as negative control administered saline orally. The $2^{\text {nd }}$ group was diabetic group, the $3^{\text {rd }}$ group treated orally with standard hypolipidemic drug atorvastatin (positive control) at a dose of $1 \mathrm{mg} / \mathrm{kg}$ twice a week. The $4^{\text {th }}$ and $5^{\text {th }}$ groups were treated daily with oral doses of 100 and $25 \mathrm{mg} / \mathrm{kg}$ bwt of ethanolic extract of Micromelum minutum seeds and Microminutinin coumarin for 1 month and 2 months, respectively. At zero time, 1 month and 2 months after administration of negative and positive controls as well extract and coumarin, blood samples were collected for total serum cholesterol, triglycerides, HDL cholesterol and LDL cholesterol determination.

\section{Determination of anti-apoptotic activity}

Principle: At the end of experimental study; the animals were sacrificed by mild ether anesthesia and the pancreas tissues were 
collected for Immunohistochemical (IHC) staining techniques allow for the visualization of antigens via sequential application of a specific antibody to the antigen (primary antibody), a secondary antibody to the primary antibody and an enzyme complex with a chromogenic substrate with interposed washing steps. The enzymatic activation of the chromogen results in a visible reaction product at the antigen site. The specimen may then be counterstained and overslipped. Results are interpreted using a light microscope [27,28]

Staining protocol: Staining procedure for $p 53$ and bcl-2 was performed according to Hsu and Raine [29] and Elias et al. [30].

Histopathological studies: At the end of experimental study; the animals were sacrificed by mild ether anesthesia. The pancreas tissues were collected, excised and rinsed in ice-cold $0.9 \%$ saline solution. They were blotted dry and fixed in $10 \%$ formalin for 48 hours. Then, they were subject to dehydration with acetone of strength 70,80 and $100 \%$ respectively each for 1hour and embedded in paraffin wax. $7.0 \mu \mathrm{m}$ thick paraffin sections of the tissue samples from control and treated animals were stained with haematoxylin-eosin for photomicroscopic observations [31].

Statistical analysis: The results are expressed as mean \pm standard error (SE). Statistical significance was determined through twoway analysis of variancs (ANOVA), followed by Student's $t$-test. P values less than 0.05 were considered statistically significant ${ }^{\star} P \leq 0.05$ significant difference compared to control (-ve control), ${ }^{* *} P \leq 0.01$ highly significant differences compared to control (-ve control). ${ }^{a} P \leq$
0.05 significant difference compared to diabetic (+ve control) group. ${ }^{b} P$ $\leq 0.01$ highly significant difference compared to diabetic (+ve control) group.

\section{Results}

TLC isolates twelve's coumarins depending on the eluate used as follow; the hexane-acetone (7:3) eluate gave micromarin-A (1) (57.9mg), micromelin (7) $(28.8 \mathrm{mg})$, murralonginol isovalerate (8) (0.4mg), microminutinin (9) (471.9mg), 6-methoxymicrominutinin (10) $(9.7 \mathrm{mg}$ ), micromarin-F (4) (10.7mg), and micromarin-G (5) (1.1mg). The hexane-acetone (1:1) eluate gave microminutin (11) (105.1mg), micromarin-H (6) (1.0mg), micromarin-C (3) (1.2mg), and murrangatin (12) $(0.5 \mathrm{mg})$. The hexane-acetone (1:4) eluate gave micromarin-B (2) $(7.5 \mathrm{mg})$. The structures of these twelve's coumarins are illustrated in Figure 1. Microminutinin coumarin (9) was used in this study due to the majority of this compound in the plant seeds.

Table 1 revealed the effect of Micromelum minutum seeds ethanolic extract and Microminutinin coumarin on serum glucose levels in diabetic rats. It is clear that there is a significant decrease in serum glucose levels after 15 and 30 days of administration of both extract and coumarin. The Micromelum minutum seeds ethanolic extract (100 $\mathrm{mg} / \mathrm{kg}$ bwt) was more effective in lowering serum glucose level than Microminutinin coumarin $(25 \mathrm{mg} / \mathrm{kg}$ bwt). Furthermore, the dose of the standard drug Glibenclamide $(2.5 \mathrm{mg} / \mathrm{kg}$ bwt $)$ was more potent in lowering effect of diabetic rats' levels than both doses of the extract and coumarin, respectively.

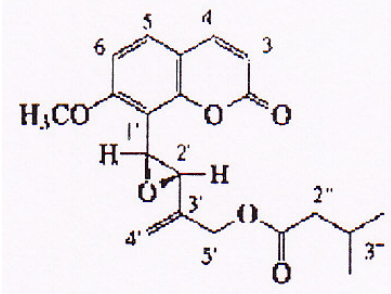

1

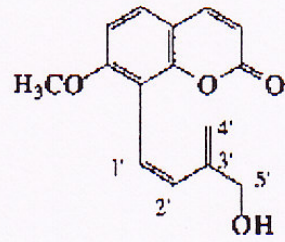

5<smiles></smiles>

9

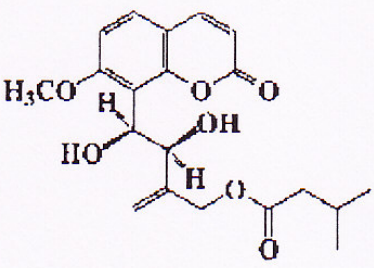

2<smiles></smiles>

6

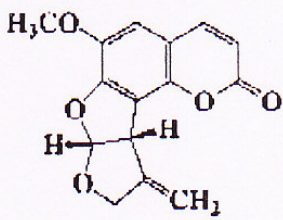

In<smiles>C=C(COC(=O)CC(C)C)[C@H](O)C(O)(O)C(O)c1c(OC)ccc2c1OC(=O)CC2</smiles>

3<smiles>COc1cc2c(cc1C1OC3(C)CCC1O3)CCC(O)O2</smiles>

7<smiles>COc1cc2c(OC)ccc3c2c(c1[C@H]1C(=O)OCC1C)OC(=O)CC3</smiles>

11<smiles>CC(C)=C(C)CO</smiles>

4<smiles>COC1CCC2CCC(=O)OC2C1C(COC(=O)CC(C)C)C(C)C</smiles>

8<smiles>C=C(C)C(O)C(O)c1c(OC)ccc2ccc(=O)oc12</smiles>

12

Figure 1: TLC of Micromelum minutum seeds extract includes twelve coumarins; micromarin- $\mathrm{A}(1)$, micromarin- $\mathrm{B}(2)$, micromarin- $\mathrm{C}(3)$, micromarin- $\mathrm{F}(4)$, micromarin-G(5), micromarin- $\mathrm{H}(6)$, micromelin(7), murralonginol isovalerate(8), microminutinin(9), 6-methoxymicrominutinin(10), microminutin(11), murrangatin(12). 
Table 2 illustrated the effect of Micromelum minutum seeds ethanolic extract and Microminutinin coumarin on serum cholesterol, triglycerides, HDL and LDL levels in diabetic rats. The data show that there was a significant decrease in the cholesterol, triglycerides and LDL levels, while an increase in the HDL level was recorded. Administration with $100 \mathrm{mg} / \mathrm{kg}$ bwt of Micromelum minutum seeds ethanolic extract exhibited a higher increase in the HDL than coumarin in dose of $25 \mathrm{mg} /$ $\mathrm{kg}$ bwt. Moreover, the dose of the standard drug Atorvastatin (1mg/ $\mathrm{kg}$ bwt) was more potent in lowering effect of hyperlipidemic rats' levels than the doses of Micromelum minutum extract and coumarin, respectively.

Table 3 exhibited the change in body weight in diabetic rats compared to control. It is clear that there is an increase in body weight in diabetic rats compared to control; while the administration of Atorvastatin, Micromelum minutum extract and coumarin, respectively at zero time, 15 days, 1 and 2 months decreased the body weight where $100 \mathrm{mg} / \mathrm{kg}$ bwt of Micromelum minutum seeds ethanolic extract exhibited a higher decrease in body weight than coumarin in dose of 25 $\mathrm{mg} / \mathrm{kg}$ bwt. Moreover, the dose of Atorvastatin ( $1 \mathrm{mg} / \mathrm{kg}$ bwt) was more potent in lowering effect of hyperlipidemic rats' levels than the dose of plant extract and coumarin, respectively.
Figure 2 showed the photomicrographs of immunohistochemically stained pancreas sections. The saline administration showed normal amount of expressed $p 53$ (Figure $2 \mathrm{~A}$ ). On the other hand, the amount of $p 53$ was potentially decreased in diabetic rats. (Figure $2 \mathrm{~B}$ ) compared to control rats. The treatment of diabetic rats with Micromelum minutum extract and Microminutinin coumarin increased the amount of expressed p53 (Figure $2 \mathrm{C}$ and D) compared to diabetic rats.

Figure 3 exhibited thephotomicrographsofimmunohistochemically stained pancreas sections where the normal rats showed normal amount of expressed bcl-2 (Figure $3 \mathrm{~A}$ ). On the other side, the amount of bcl-2 was potentially increased in diabetic rats (Figure $3 \mathrm{~B}$ ). The treatment of diabetic rats with either dose of Micromelum minutum extract and Microminutinin coumarin potentially decreased the elevated amount of expressed bcl-2 (Figure $3 \mathrm{C}$ and D) as compared to diabetic group.

Histopathological investigation of the pancreas of control and diabetic rats are shown in Figure 4, A-D. Pancreas of normal control animals showed normal islets, whereas that of diabetic animals showed atrophy of $\beta$-cells and vascular degenerative changes in the islets. Micromelum minutum seeds ethanolic extract $(100 \mathrm{mg} / \mathrm{kg})$ and Microminutinin coumarin $(25 \mathrm{mg} / \mathrm{kg}$ bwt $)$ treatment increased the number of islets as compared to that of diabetic animals.

\begin{tabular}{|c|c|c|c|}
\hline \multirow{2}{*}{ Groups } & \multicolumn{3}{|c|}{ Serum glucose (mg/dl) } \\
\cline { 2 - 4 } & Zero & 15 days & $\mathbf{3 0}$ days \\
\hline Control $(1 \mathrm{ml}$ saline) & $90.65 \pm 2.92$ & $92.16 \pm 2.78$ & $96.50 \pm 3.27$ \\
\hline Diabetes & $215.43 \pm 4.16^{* *}$ & $249.27 \pm 5.27^{* *}$ & $258.10 \pm 4.62^{* *}$ \\
\hline Diabetes + Glibenclamide $(2.5 \mathrm{mg} / \mathrm{kg})$ & $209.48 \pm 3.05^{* \star}$ & $110.16 \pm 2.88^{* * \mathrm{~b}}$ & $102.85 \pm 2.43^{\mathrm{b}}$ \\
\hline Diabetes + Micromelum minutum extract $(100 \mathrm{mg} / \mathrm{kg} \mathrm{bwt})$ & $208.56 \pm 2.61^{* *}$ & $115.60 \pm 2.18^{* * \mathrm{~b}}$ & $105.24 \pm 2.38^{\star \mathrm{b}}$ \\
\hline Diabetes + Diabetes Microminutinin coumarin $(25 \mathrm{mg} / \mathrm{kg}$ bwt) & $209.40 \pm 2.89^{* *}$ & $120.45 \pm 2.82^{* * \mathrm{~b}}$ & $108.45 \pm 2.91^{* \mathrm{~b}}$ \\
\hline
\end{tabular}

Results expressed as mean \pm SE $(n=8)$, *Significantly difference from control at $P \leq 0.05$, ** Highly significantly difference from control at $P \leq 0.01$, aSignificantly difference from diabetes at $P \leq 0.05$, bHighly significantly difference from diabetes at $P \leq 0.01$, Saline, Glibenclamide, plant seeds extract and Microminutinin were given in the same volume $(1 \mathrm{ml})$. Serum glucose was measured at Zero, 15 \& 30 days of Saline, Glibenclamide, Extract and Microminutinin administration.

Table 1: Effect of ethanolic extract of Micromelum minutum seeds and Microminutinin coumarin on diabetic rats.

\begin{tabular}{|c|c|c|c|c|}
\hline \multirow{2}{*}{ Group } & \multirow{2}{*}{ Parameters (mg/dl) } & \multicolumn{3}{|c|}{ Time } \\
\hline & & Zero & 1 month & 2 months \\
\hline \multirow{4}{*}{ Control (1ml saline) } & Cholesterol & $160.2 \pm 6.6$ & $168.7 \pm 7.3$ & $171.8 \pm 8.4$ \\
\hline & Triglycerides & $149.4 \pm 7.3$ & $154.8 \pm 7.7$ & $159.2 \pm 8.2$ \\
\hline & $\mathrm{HDL}$ & $18.2 \pm 0.6$ & $17.8 \pm 0.8$ & $17.9 \pm 0.6$ \\
\hline & LDL & $105.9 \pm 6.4$ & $109.4 \pm 7.6$ & $112.3 \pm 8.8$ \\
\hline \multirow{4}{*}{ Diabetes } & Cholesterol & $170.2 \pm 7.2$ & $196.5 \pm 6.3^{* *}$ & $215.6 \pm 9.2^{* \star}$ \\
\hline & Triglycerides & $148.0 \pm 5.9$ & $169.8 \pm 7.1^{* *}$ & $180.4 \pm 7.9^{* *}$ \\
\hline & $\mathrm{HDL}$ & $18.9 \pm 1.8$ & $16.5 \pm 0.9^{* *}$ & $15.8 \pm 0.7^{* *}$ \\
\hline & LDL & $121.3 \pm 6.1$ & $130.4 \pm 6.8^{* *}$ & $142.3 \pm 9.0^{* *}$ \\
\hline \multirow{4}{*}{$\begin{array}{l}\text { Diabetes + Atorvastatin } \\
\quad(1 \mathrm{mg} / \mathrm{kg} \text { bwt })\end{array}$} & Cholesterol & $161.0 \pm 6.2$ & $114.6 \pm 6.7^{* \star \mathrm{b}}$ & $89.5 \pm 4.8^{* * \mathrm{~b}}$ \\
\hline & Triglycerides & $143.7 \pm 8.5$ & $90.8 \pm 4.8^{* * \mathrm{~b}}$ & $71.0 \pm 3.5^{* * \mathrm{~b}}$ \\
\hline & $\mathrm{HDL}$ & $19.1 \pm 1.0$ & $35.0 \pm 1.8^{* * \mathrm{~b}}$ & $42.8 \pm 2.3^{* * b}$ \\
\hline & LDL & $113.2 \pm 5.8$ & $63.6 \pm 2.2^{* \star b}$ & $29.9 \pm 1.6^{* * \mathrm{~b}}$ \\
\hline \multirow{4}{*}{$\begin{array}{c}\text { Diabetes + Micromelum } \\
\text { minutum extract }(100 \mathrm{mg} / \mathrm{kg} \text { bwt })\end{array}$} & Cholesterol & $169.6 \pm 6.6$ & $118.9 \pm 6.7^{* * \mathrm{~b}}$ & $94.1 \pm 4.8^{* * \mathrm{~b}}$ \\
\hline & Triglycerides & $145.2 \pm 5.2$ & $96.9 \pm 4.8^{* * \mathrm{~b}}$ & $73.2 \pm 3.5^{* * \mathrm{~b}}$ \\
\hline & $\mathrm{HDL}$ & $18.8 \pm 1.3$ & $36.1 \pm 1.8^{* * \mathrm{~b}}$ & $46.8 \pm 2.3^{* * \mathrm{~b}}$ \\
\hline & LDL & $118.2 \pm 6.3$ & $65.2 \pm 2.2^{* * b}$ & $29.4 \pm 1.6^{\star * b}$ \\
\hline \multirow{4}{*}{$\begin{array}{l}\text { Diabetes + Microminutinin } \\
\text { coumarin }(25 \mathrm{mg} / \mathrm{kg} \text { bwt })\end{array}$} & Cholesterol & $171.5 \pm 6.2$ & $131.6 \pm 5.9^{* * \mathrm{~b}}$ & $119.1 \pm 5.5^{* * \mathrm{~b}}$ \\
\hline & Triglycerides & $147.6 \pm 5.5$ & $114.8 \pm 4.7^{* \star \mathrm{b}}$ & $89.7 \pm 4.6^{\star \star b}$ \\
\hline & HDL & $18.5 \pm 1.2$ & $28.2 \pm 1.3^{* * b}$ & $38.5 \pm 1.5^{\star \star \mathrm{b}}$ \\
\hline & LDL & $120.6 \pm 4.7$ & $78.9 \pm 4.2^{* * \mathrm{~b}}$ & $31.8 \pm 3.5^{* * \mathrm{~b}}$ \\
\hline
\end{tabular}

Results expressed as mean \pm SE $(n=8)$, **Significantly difference from control at $P \leq 0.01$, b significantly difference from diabetes at $P \leq 0.01$, Saline, Atorvastatin, plant seeds extract and Microminutinin were given in the same volume $(1 \mathrm{ml})$. Lipid profile was measured at Zero, 1 \& 2 months of Saline, Atorvastatin, Extract and Microminutinin administration.

Table 2: Effect of ethanolic extract of Micromelum minutum seeds and Microminutinin coumarin on lipid profile of diabetic rats 
Citation: Koriem KMM, Aminuddin ME, Kader AS, Sheikh NR (2013) Antihyperglycemic, Antihyperlipidemic and Antiapoptotic Activities of Micromelum Minutum Seeds in Diabetic Rats. J Mol Genet Med S1: 004. doi: 10.4172/1747-0862.S1-004

Page 5 of 8

\begin{tabular}{|c|c|c|c|c|}
\hline \multirow{2}{*}{ Group } & \multicolumn{4}{|c|}{ Body weight (g) } \\
\hline & Zero & 15 days & 1 month & 2 months \\
\hline Control ( $1 \mathrm{ml}$ saline) & $201.6 \pm 1.2$ & $205.17 \pm 0.8$ & $210.2 \pm 0.6$ & $207.4 \pm 0.9$ \\
\hline Diabetes & $213.1 \pm 1.5^{\star *}$ & $219.12 \pm 1.1^{* *}$ & $221.2 \pm 1.1^{* *}$ & $225.6 \pm 0.02^{* *}$ \\
\hline Diabetes + Atorvastatin (1 mg/kg bwt) & $226.9 \pm 0.8$ & $206.2 \pm 1.2^{\mathrm{b}}$ & $201.3 \pm 0.9^{b}$ & $193.9 \pm 1.7^{b}$ \\
\hline Diabetes + Micromelum minutum extract (100mg/kg bwt) & $222.3 \pm 0.6$ & $213.3 \pm 1.0^{\mathrm{a}}$ & $205.1 \pm 1.4^{b}$ & $198.6 \pm 0.8^{b}$ \\
\hline Diabetes + Microminutinin coumarin (25mg/kg bwt) & $228.4 \pm 0.7$ & $216.1 \pm 0.1^{\mathrm{a}}$ & $211.2 \pm 2.6^{\mathrm{b}}$ & $202.2 \pm 1.5^{\mathrm{b}}$ \\
\hline
\end{tabular}

Data represents mean \pm SE $(n=8),{ }^{* *}$ highly significantly difference from control at $P \leq 0.01$; a Significantly difference from diabetes at $P \leq 0.05$, b Highly significantly difference from diabetes at $\mathrm{P} \leq 0.01$, Saline, Atorvastatin, plant seeds extract and Microminutinin were given in the same volume (1 $\mathrm{ml})$. Body weight was measured at Zero, 15 days, 1 \& 2 months of Saline, Atorvastatin, Extract and coumarin administration

Table 3: Effect of ethanolic extract of Micromelum minutum seeds and Microminutinin coumarin on body weight of diabetic rats.
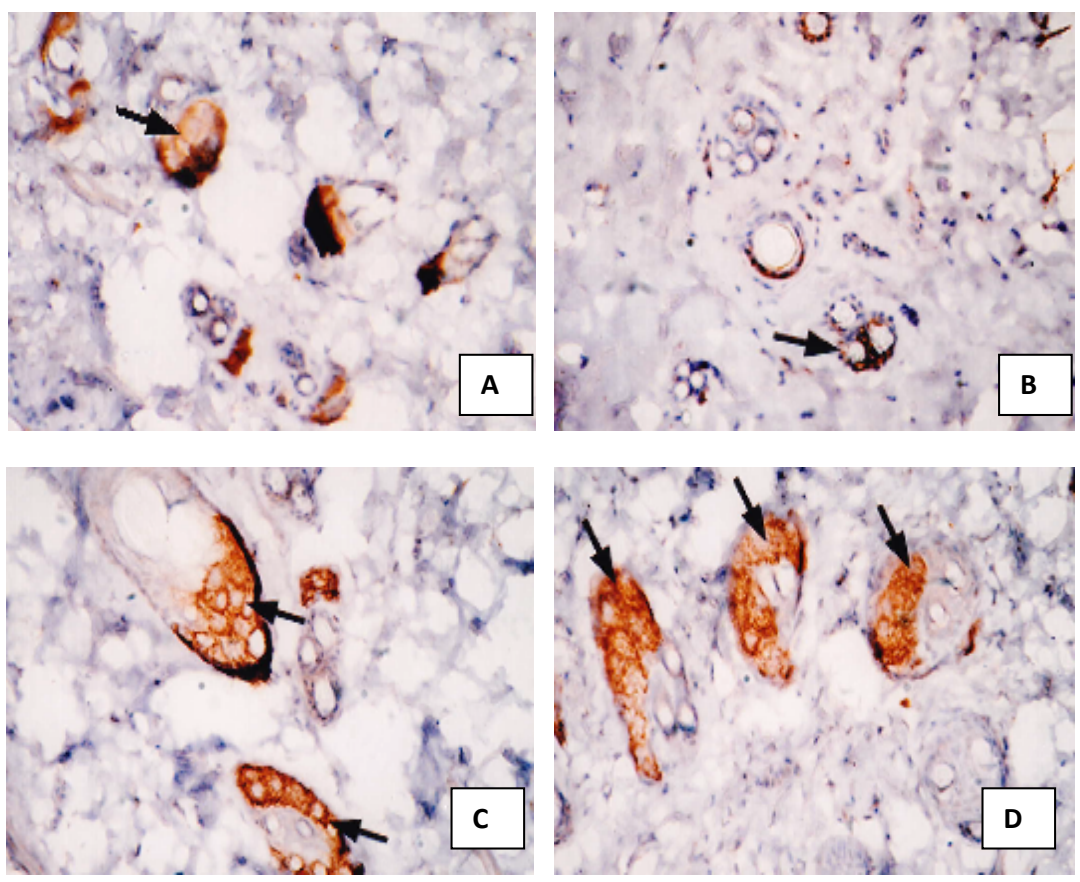

Figure 2: (A) Immunohistochemically-stained pancreas tissue sections showing apoptotic marker, p53 expression in control rats. (B) Immunohistochemicallystained pancreas tissue sections showing the apoptotic marker $p 53$ expression in diabetic rats. (C) Immunohistochemically-stained pancreas tissue sections showing the effect of Micromelum minutum seeds extract on apoptotic marker p53 expression in diabetic rats. (D) Immunohistochemicaly-stained kidney tissue sections showing the effect of Microminutinin coumarin on apoptotic marker p53 expression in diabetic rats.

\section{Discussion}

Pharmacological studies on the Micromelum minutum seeds (Family Rutaceae) grown in Malaysia are limited. The selection of the plant Micromelum minutum due to it's widely distribution in Southeast Asia and the Pacific Islands where the leaves are used traditionally as a febrifuge, the stems as a carminative, and the flowers and fruits as an expectorant and a purgative, respectively [9]. In this study the evaluation of antihyperglycemic, antihyperlipidemic and antiapoptotic Activities of Micromelum minutum in diabetic rats was done.

In the present study, the effects of the Micromelum minutum seeds ethanolic extract and Microminutinin coumarin on serum glucose levels in diabetic rats were done. The result revealed that there is a significant decrease in glucose levels after extract $(100 \mathrm{mg} / \mathrm{kg}$ bwt $)$ and coumarin $(25 \mathrm{mg} / \mathrm{kg}$ bwt) administration. Coumarins are reported to have antioxidant activity and preserve the levels of other antioxidants in human plasma $[32,33]$. Coumarins also inhibited lipid peroxidation and increased the activity of antioxidants, superoxide dismutase and catalase [34]. Micromelum minutum seeds extract significantly reduced the blood glucose levels of diabetic rats indicating that the mechanism of action may be due to coumarin ingredient; where coumarin inhibits hyperglycemia [34,35]. Hyperglycemia inhibits antioxidants and its cellular transport. Since the chemical structure of antioxidants is similar to that of glucose, it shares the membrane transport system with glucose and hence competes with it for its transport, where glucose-lysine mixtures (GL) at $150^{\circ} \mathrm{C}$ increased the ability to reduce lipid peroxidation and decreased the free radical scavenging activity [36]. Thus the elevation in glucose concentration may depress natural antioxidants inside the body. Therefore when coumarin is supplied from exogenous source as from Micromelum minutum seeds, it is able to do its antioxidant duty and protect the pancreas and decrease serum glucose. These observations were supported by Von Stebut et al. [37] who succeeded to obtain a successful treatment of adult multisystemic langerhans cell histiocytosis from coumarin.

In this study, the effects of the Micromelum minutum seeds extract and Microminutinin coumarin on serum cholesterol, triglycerides, HDL and LDL levels in diabetic rats were done. The result revealed that there is a significant decrease in the cholesterol, triglycerides and LDL; while an increase in HDL concentrations after extract and coumarin administration. Administration with $25 \mathrm{mg} / \mathrm{kg}$ bwt of coumarin 
Citation: Koriem KMM, Aminuddin ME, Kader AS, Sheikh NR (2013) Antihyperglycemic, Antihyperlipidemic and Antiapoptotic Activities of Micromelum Minutum Seeds in Diabetic Rats. J Mol Genet Med S1: 004. doi: 10.4172/1747-0862.S1-004
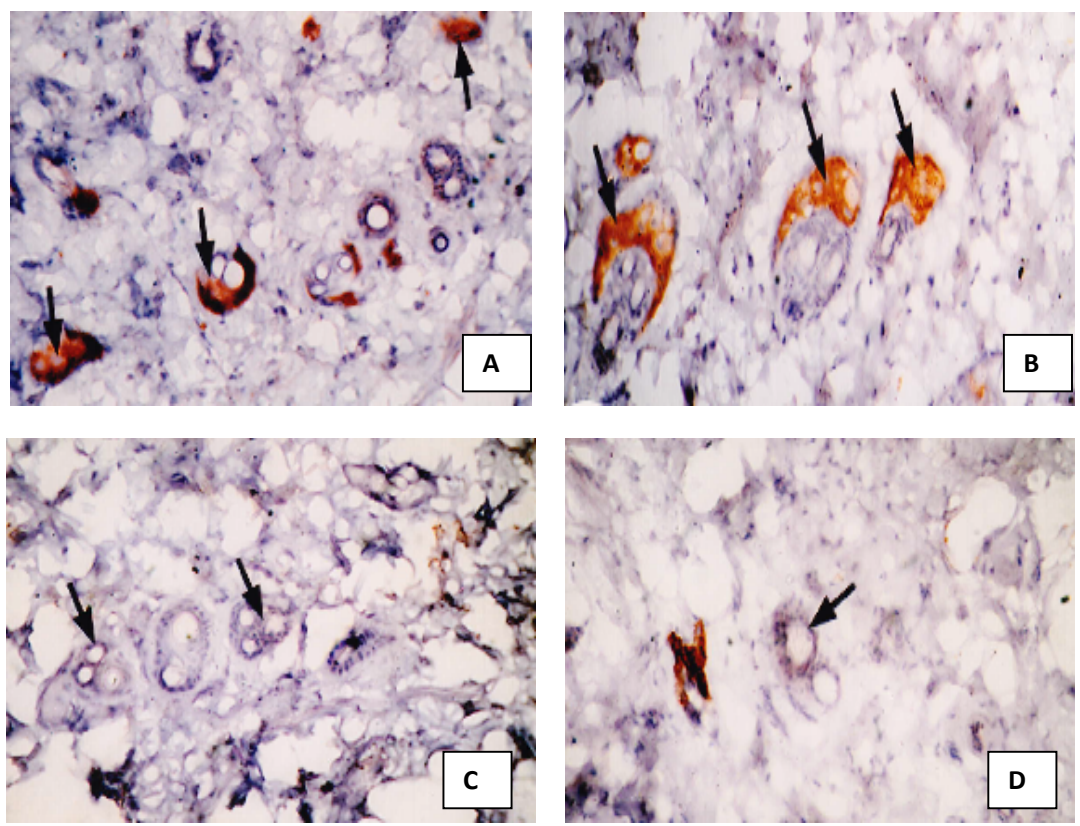

Figure 3: (A) Immunohistochemically-stained pancreas tissue sections showing anti-apoptotic marker, bcl-2 expression in control rats. (B) Immunohistochemicallystained pancreas tissue sections showing the anti-apoptotic marker bcl-2 expression in diabetic rats. (C) Immunohistochemicaly-stained pancreas tissue sections showing the effect of Micromelum minutum seeds extract on anti-apoptotic marker bcl-2 expression in diabetic rats. (D) Immunohistochemically-stained pancreas tissue sections showing the effect of Microminutinin coumarin on anti- apoptotic marker bcl-2 expression in diabetic rats.
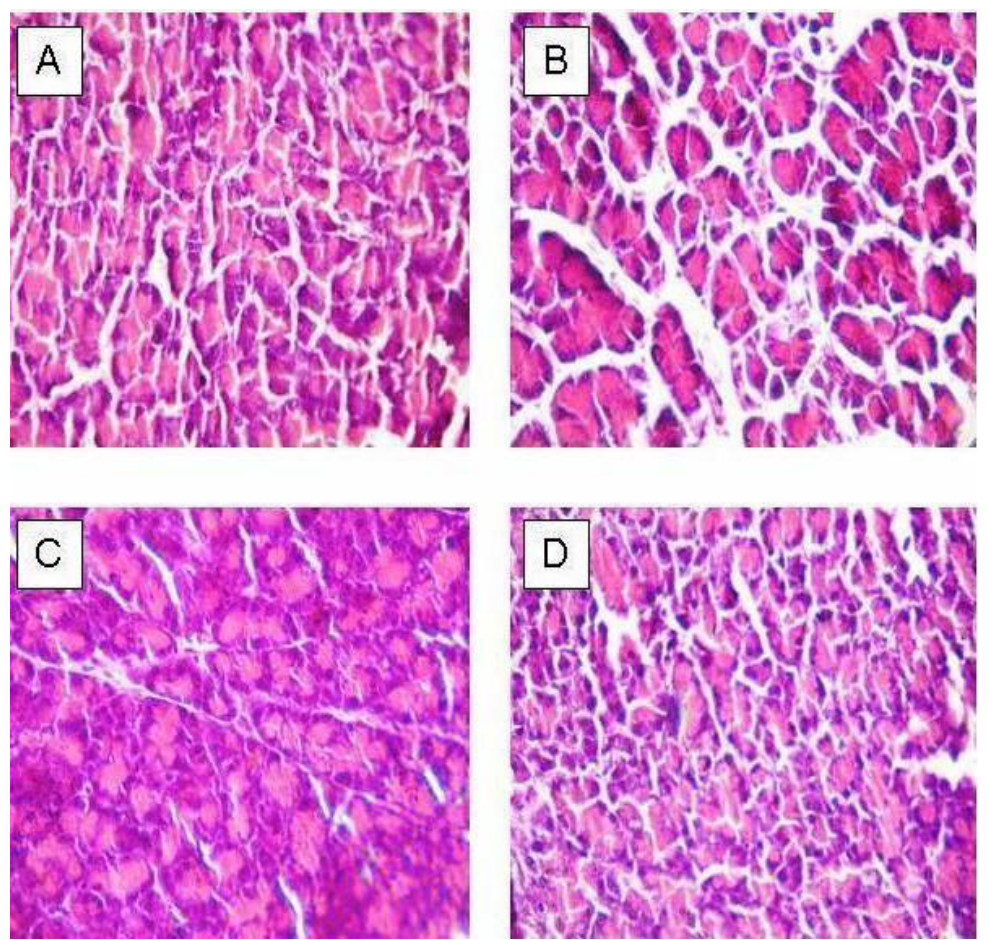

Figure 4: Histological examinations of experimental rat pancreas, (A) Normal control rat pancreas showing patches of abundant $\beta$-cells. (B) Pancreas of diabetic rat showing minimal number of pancreatic $\beta$-cells. (C) Pancreas of diabetic rat after treatment with Micromelum minutum seeds ethanolic extract (100 mg/kg) showing pancreatic $\beta$-cells almost similar to that of control. (All figures are in 10x magnification). (D) Pancreas of diabetic rat after treatment with Microminutinin coumarin $(25 \mathrm{mg} / \mathrm{kg}$ bwt), showing pancreatic $\beta$-cells similar to that of the control.

exhibited a significant increase in HDL value, while $100 \mathrm{mg} / \mathrm{kg}$ bwt of the plant extract also showed a significant increase in HDL value but higher; which is considered a beneficiary effect in the treatment of dyslipidemia condition. The HDL mediates the reverse transport of cholesterol from peripheral tissues to the liver for disposal by excretion into bile. This process will disallow the slow accumulation of lipids in 
artery walls. This effect may be attributed to the coumarin contents of the plant seeds which was reported to exhibit lipid lowering effect and significantly decrease total cholesterol level [38-40].

In this study, increase in body weight in diabetic rats was observed. However, obesity, which represents one of the main features of the metabolic syndrome, is commonly associated with diabetes syndrome [41]. The administration of both Micromelum minutum seeds extract and Microminutinin coumarin Micromelum minutum seeds extract and Microminutinin coumarin to diabetic rats decrease body weight. These results are in agreement with that of Pari and Rajarajeswari [42] and Guerrero-Analco et al. [35] who reported that the administration of coumarin to diabetic rats resulted in alterations in the metabolism of glucose with subsequent reduction in plasma glucose levels and body weight.

In the current study, anti-apoptotic activity of Micromelum minutum seeds extract and Microminutinin coumarin were recorded. p53 and bcl-2 are closely related to the majority of human toxicity and cancer [43]. Apoptotic marker, $p 53$ is a critical regulator of apoptosis in many cells. It stimulates a wide network of signals that act through either extrinsic or intrinsic pathways of apoptosis [44] by activating the transcription of downstream genes such as p21 and Bax to induce apoptotic process which inhibiting the growth of cells with damaged DNA. On the other hand, bcl-2 has been reported to function primarily by blocking the apoptosis pathway [45]. Bcl-2 gene product is a negative regulator of apoptosis, which forms a heterodimer complex with Bax and neutralizes the effect of pro-apoptosis [46]. Our results indicated that diabetes decreased $p 53$ expression while increased bcl-2 expression. On the other side, the treated with Micromelum minutum seeds extract and its coumarin ingredient to diabetic rats increased p53 expression while decreased bcl-2 expression. These results were in agreement with that of Mulware [47] who reported that diabetes cause induction of oxidative-induced DNA damage by ROS may lead to isolated base lesions or single-strand breaks, complex lesions like double-strand breaks, and some oxidative generated clustered DNA lesions (OCDLs) which are linked to cell apoptosis and mutagenesis. On the other side, coumarin has anti-apoptotic activity, an inhibitor of $p 53$ abrogated glucolipotoxicity-induced ROS generation and $p 53$ expression [48]. The antiapoptotic activity of Micromelum minutum may be related to its mahanine ingredient (a carbazole alkaloid occurs in Micromelum minutum; where concentration of $10 \mu \mathrm{M}$ mahanine caused a complete inhibition of cell proliferation and the induction of apoptosis in a time dependent manner. Mahanine-induced cell death was characterized with the changes in nuclear morphology, DNA fragmentation, activation of caspase like activities, poly (ADPribose) polymerase cleavage, release of cytochrome $c$ into cytosol and stimulation of reactive oxygen species generation. The mahanine activated various caspases such as caspase- $3,-6,-8$ and -9 (like) activities but not caspase- 1 like activity. More than $70 \%$ cell survival was observed in the presence of a caspase- 3 inhibitor. The overall results suggested that mahanine down regulates cell survival factors by activation of caspase- 3 through mitochondrial dependent pathway, and disrupts cell cycle progression [49,50]. High blood glucose levelsinduced apoptosis by regulating the gene expression of the bcl-2 and p53; where bcl-2 expression stimulated by high glucose level [51].

Histopathological studies of pancreas of control and diabetic rats of both Micromelum minutum seeds ethanolic extract- and Microminutinin coumarin-treated groups indicate that the plant ethanolic extract has cytoprotective properties.

In this study; we find out that these major amounts of coumarins in Micromelum minutum seeds ethanolic extract are responsible for all plant seeds activities; and the plant ethanolic extract was more potent in its activities than its Microminutinin coumarin. This may be related to synergistic effects among different coumarins contents of the plant seeds ethanolic extract.

Micromelum minutum seeds are used in Malaysia as a house remedy and people are used to drink it without a known acceptable dose. From this study, we found that $100 \mathrm{mg} / \mathrm{kg}$ bt Micromelum minutum seeds ethanolic extract was more potent in all activities studied; so if human standard weight was $70 \mathrm{~kg}$; then $7 \mathrm{~g}$ of seeds ethanolic extract was recommended for human daily consumption. In this study we collected $1.5 \mathrm{~kg}$ of the plant seeds to obtain finally $150 \mathrm{~g}$ of Micromelum minutum seeds ethanolic extract; so $70 \mathrm{~g}$ of Micromelum minutum seeds in divided doses was the equivalence of recommended daily amount for human consumption of raw herb (seeds of Micromelum minutum) used for this study and the clinical treatment requires management by a health-care provider.

\section{Conclusion}

According to the previous data, it could be concluded that Micromelum minutum seeds extract could be used for the treatment of hyperglycemia, hyperlipidemia and apoptosis. Coumarins contents are responsible for all these activities of plant seeds ethanolic extract. However, further clinical studies are warranted to establish it's effectiveness in humans and it will be interesting to see whether Micromelum minutum seeds can reverses existing complications associated with diabetes, like in real case scenarios.

\section{Conflict of Interest Statement}

The authors declare that there are no conflicts of interest.

\section{Refereneces}

1. McCarty P; Zimmet P (1997) “Diabetes 1994-2010 global estimate and projection," Diabetic Care 20: 1785-1793.

2. American Diabetes Association (2007) "Diagnosis and classification of diabetes mellitus," Diabetic Care 30: S42-S46.

3. Kumar S; Kumar V; O. Prakash O (2011) "Antidiabetic and antihyperlipidemic effects of Dillenia indica (L.) leaves extract.” Brazilian J Pharma Sci 47:1-6.

4. Kumar S, Kumar V, Prakash O (2011) Antidiabetic, hypolipidemic and histopathological analysis of Dillenia indica (L.) leaves extract on alloxan induced diabetic rats. Asian Pac J Trop Med 4: 347-352.

5. Newman DJ, Cragg GM, Snader KM (2003) Natural products as sources of new drugs over the period 1981-2002. J Nat Prod 66: 1022-1037.

6. Girija K, Lakshman K, Udaya C, Sabhya SG, Divya T (2011) Anti-diabetic and anti-cholesterolemic activity of methanol extracts of three species of Amaranthus. Asian Pac J Trop Biomed 1: 133-138.

7. WHO (1980) "Expert committee on diabetes mellitus" Technical Report Series 646, World Health Organization, Geneva, Switzerland, 05-112.

8. Smitinand T (2001) Thai, English, Book edition: Thai plant names 214-228.

9. Pongboonrod S (1950) Mai Thed Muang Thai. Kaseambunnakit Printing, Bangkok, Thailand; 428-429. (in Thailand).

10. Cassady JM, Ojima N, Chang C, McLaughlin JL (1979) An investigation of the antitumor activity of Micromelum integerrimum (Rutaceae). J Nat Prod 42: 274-278.

11. Das S, Kellermann E, Hollenberg CP (1984) Transformation of Kluyveromyces fragilis. J Bacteriol 158: 1165-1167.

12. Kamperdick C, Phuong N M, Sun TV, Schmidt J (1999) Adam G. 7-methoxy-6[(1R,2R,5R)-5- methyl-4-oxo-3-one. Phytochem 52: 1671-1676.

13. Tantivatana P, Ruana GM, Vaisiriroj V, Lankin DC, Bhacca MC, et al. (1983) (1R,3R,4R,6S)-4-(7-Methoxy-2-oxo-2H-chromen-6-yl)-1-methyl-3,6-one. J Org Chem 48: 268-270. 
14. Tantishaiyakul V, Pummangura S, Chaichantipyuth C, Ma WW, McLaughlin JL (1986) Phebalosin from the bark of Micromelum minutum. J Nat Prod 49: 180-181.

15. Rahmani M, Yu C, Dai Y, Reese E, Ahmed W, et al. (2003) Coadministration of the heat shock protein 90 antagonist 17-allylamino- 17-demethoxygeldanamycin with suberoylanilide hydroxamic acid or sodium butyrate synergistically induces apoptosis in human leukemia cells. Cancer Res 63: 8420-8427.

16. Lekphrom R, Kanokmedhakul S, Kukongviriyapan V, Kanokmedhakul K (2011) C-7 oxygenated coumarins from the fruits of Micromelum minutum. Arch Pharm Res 34: 527-531.

17. Nakahara K, Hayashi T, Konishi S, Miyashita Y (2002) Functional MRI of macaque monkeys performing a cognitive set-shifting task. Science 295: 1532 1536.

18. Sakunpak A, Matsunami K, Otsuka H, Panichayupakaranant $P(2013)$ Isolation of new monoterpene coumarins from Micromelum minutum leaves and their cytotoxic activity against Leishmania major and cancer cells. Food Chem 139 458-463.

19. Chopra RN, Nayar SL, Chopra IC (1986) Glossary of Indian Medicinal Plants (including the supplement). Council of Scientific and industrial Research, New Delhi, India 402-405.

20. Farnsworth NR (2001) Ed. NAPRALERT database. Chicago, IL, University of Illinois at Chicago, 47-51.

21. Leung AY, Foster S (1996) Encyclopedia of common natural ingredients used in food, drugs and cosmetics. New York, NY, John Wiley and Sons 84-92.

22. Behren W, Karber G (1953) Determination of LD50. Arch Exper Path Pharma 2: 177-272.

23. Koriem KM, Arbid MS, El-Gendy NF (2010) The protective role of Tropaeolum majus on blood and liver toxicity induced by diethyl maleate in rats. Toxico Mech Methods 20: $579-586$

24. Paget G, Bernes E (1964) Toxicity tests in evaluation of drug activities sited in labotatory rats. Laurence,D.R. and A.L. Bacarach. Academic Press London $135-160$

25. Trinder $P$ (1969) Determination of glucose in blood using glucose oxidase with an alternative acceptor. Ann Clin Biochem 6: 24-27.

26. Dholi SK, Raparla R, Mankal SK, Nagappan K (2011) Invivo Antidiabetic evaluation of Neem leaf extract in alloxan induced rats. J Appl Pharma Sci 01: 100-105.

27. Omata M, Liew CT, Ashcavai M, Peters RL (1980) Nonimmunologic binding of horseradish peroxidase to hepatitis $B$ surface antigen. A possible source of error in immunohistochemistry. Am J Clin Pathol 73: 626-632.

28. Tweddle DA, Malcolm AJ, Cole M, Pearson AD, Lunec J (2001) p53 cellular localization and function in neuroblastoma: evidence for defective $\mathrm{G}(1)$ arrest despite WAF1 induction in MYCN-amplified cells. Am J Pathol 158: 2067-2077.

29. Hsu SM, Raine L (1984) In "Advances in Immunochem DeLellis, R. A. Ed Mason Publishing USA, Inc., New York 31-42.

30. Elias JM, Margiotta M, Gaborc D (1989) Sensitivity and detection efficiency of the peroxidase antiperoxidase (PAP), avidin-biotin peroxidase complex (ABC), and peroxidase-labeled avidin-biotin (LAB) methods. Am J Clin Pathol 92: 62-67.

31. Bora PS, Srivastava LM, Bhatt SD (1985) Metabolic and histopathological effects of streptozotocin induced diabetes in rats: effect of propranolol and insulin. Indian J Exp Biol 23: 23-26.

32. Hadjipavlou-Litina D, Kontogiorgis C, Pontiki E, Dakanali M, Akoumianaki A et al. (2007) Anti-inflammatory and antioxidant activity of coumarins designed as potential fluorescent zinc sensors. J Enzyme Inhib Med Chem 22: 287-292.

33. Leal LK, Ferreira AA, Bezerra GA, Matos FJ, Viana GS (2000) Antinociceptive anti-inflammatory and bronchodilator activities of Brazilian medicinal plants containing coumarin: a comparative study. J Ethnopharmacol 70: 151-159.

34. Panda S, Kar A (2006) Evaluation of the antithyroid, antioxidative and antihyperglycemic activity of scopoletin from Aegle marmelos leaves in hyperthyroid rats. Phytother Res 20: 1103-1105.

35. Guerrero-Analco JA, Hersch-Martínez P, Pedraza-Chaverri J, Navarrete A Mata R (2005) Antihyperglycemic effect of constituents from Hintonia standleyana in streptozotocin-induced diabetic rats. Planta Med 71: 1099-1105.

36. Ruiz-Roca B, Navarro MP, Seiquer I (2008) Antioxidant properties and metal chelating activity of glucose-lysine heated mixtures: relationships with mineral absorption across Caco-2 cell monolayers. J Agric Food Chem 56: 9056-9063.

37. von Stebut E, Schadmand-Fischer S, Bräuninger W, Kreft A, Doberauer C, et al. (2008) Successful treatment of adult multisystemic Langerhans cell histiocytosis with psoralen-UV-A, prednisolone, mercaptopurine, and vinblastine. Arch Dermatol 144: 649-653.

38. Yuce B, Danis O, Ogan A, Sener G, Bulut M, et al. (2009) Antioxidative and lipid lowering effects of 7,8-dihydroxy-3- (4-methylphenyl) coumarin in hyperlipidemic rats. Arzneimittelforschung 59: 129-134.

39. Sashidhara KV, Kumar A, Kumar M, Srivastava A, Puri A (2010) Synthesis and antihyperlipidemic activity of novel coumarin bisindole derivatives. Bioorg Med Chem Lett 20: 6504-6507.

40. Koriem KM, Asaad GF, Megahed HA, Zahran H, Arbid MS (2012) Evaluation of the antihyperlipidemic, anti-inflammatory, analgesic, and antipyretic activities of ethanolic extract of Ammi majus seeds in albino rats and mice. Int $\mathrm{J}$ Toxico 31: 294-300.

41. Asrih M, Jornayvaz FR (2013) Diets and nonalcoholic fatty liver disease: The good and the bad. Clin Nutr.

42. Pari L, Rajarajeswari N (2009) Efficacy of coumarin on hepatic key enzymes of glucose metabolism in chemical induced type 2 diabetic rats. Chem Bio Interact 181: 292-296.

43. Gu Q, Hu C, Chen Q, Xia Y, Feng J, et al. (2009) Development of a rat model by 3,4-benzopyrene intra-pulmonary injection and evaluation of the effect of green tea drinking on $\mathrm{p} 53$ and bcl-2 expression in lung carcinoma. Cancer Detect Prev 32: 444-451.

44. Yerlikaya A, Okur E, Ulukaya E (2012) The p53-independent induction of apoptosis in breast cancer cells in response to proteasome inhibitor bortezomib. Tumour Biol 33: 1385-1392.

45. Hussein AM, Ahmed OM (2010) Regioselective one-pot synthesis and anti-proliferative and apoptotic effects of some novel tetrazolo[1,5-a]pyrimidine derivatives. Bioorg Med Chem 18: 2639-2644.

46. Chaudhary SC, Siddiqui MS, Athar M, Alam MS (2012) D-Limonene modulates inflammation, oxidative stress and Ras-ERK pathway to inhibit murine skin tumorigenesis. Hum Exp Toxicol 31: 798-811.

47. Mulware SJ (2013) Comparative Trace Elemental Analysis in Cancerous and Noncancerous Human Tissues Using PIXE. J Biophys 2013: 192026.

48. Wang HJ, Lee EY, Han SJ, Kim SH, Lee BW, et al. (2012) Dual pathways of p53 mediated glucolipotoxicity-induced apoptosis of rat cardiomyoblast cell: activation of p53 proapoptosis and inhibition of Nrf2-NQO1 antiapoptosis. Me tabolism 61: 496-503.

49. Roy MK, Thalang VN, Trakoontivakorn G, Nakahara K (2004) Mechanism of mahanine-induced apoptosis in human leukemia cells (HL-60). Biochem Pharmacol 67: 41-51.

50. Roy MK, Thalang VN, Trakoontivakorn G, Nakahara K (2005) Mahanine, a carbazole alkaloid from Micromelum minutum, inhibits cell growth and induces apoptosis in U937 cells through a mitochondrial dependent pathway. $\mathrm{Br} \mathrm{J}$ Pharmacol 145: $145-155$

51. Ye P, Lin K, Li Z, Liu J, Yao K, et al. (2013) [(-)-Epigallocatechin gallate regulates expression of apoptotic genes and protects cultured human lens epithelia cells under hyperglycemia]. Mol Biol (Mosk) 47: 251-257.

This article was originally published in a special issue, Molecular \& Cellular Aspects in Obesity \& Diabetes handled by Editor(s). Dr. Masayoshi Yamaguchi, Emory University School of Medicine, USA 